\title{
Bacterial Peritonitis
}

National Cancer Institute

\section{Source}

National Cancer Institute. Bacterial Peritonitis. NCI Thesaurus. Code C128407.

Peritonitis that is caused by a bacterial infection. 